Supplement of Clim. Past, 16, 299-313, 2020

https://doi.org/10.5194/cp-16-299-2020-supplement

(c) Author(s) 2020. This work is distributed under

the Creative Commons Attribution 4.0 License.

(c) (1)

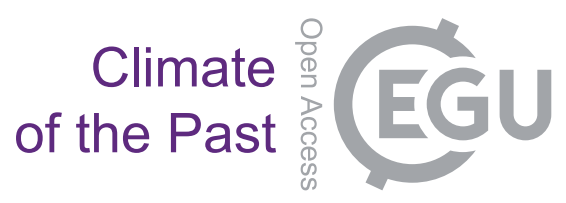

Supplement of

\title{
Late Pliocene Cordilleran Ice Sheet development with warm northeast Pacific sea surface temperatures
}

Maria Luisa Sánchez-Montes et al.

Correspondence to: Maria Luisa Sánchez-Montes (m.sanchez-montes@uea.ac.uk)

The copyright of individual parts of the supplement might differ from the CC BY 4.0 License. 


\section{Supplement information}

A shipboard composite depth scale was generated for Site U1417 to take into account the recovery of sediments from multiple holes. A continuous "splice" spanning the upper and middle Pleistocene sediments was generated from 0-224.2 m core composite depth ("CCSF-A"; Jaeger et al., 2014). Below this depth, and especially where coring switched from the APC

5 (advanced piston corer) to the XCB (extended core barrel) system, core recovery was reduced from $\sim 97 \%$ (APC) to $37 \%$ (XCB). The recovered sediments tended to be in "biscuits" of coherent sediment; without knowledge of where these biscuits had originally been distributed within the $9.5 \mathrm{~m}$ core, they were grouped into the uppermost portions of each core (e.g. if 3 $\mathrm{m}$ of sediments were recovered, they were placed into the 0-3 $\mathrm{m}$ depth interval for each core). This leads to a clustering of recovered sediment and proxy data (Fig. S1 and Fig. S2). There is a possibility that recovery problems such as movement of

10 sediment through the liner during sediment recovery and logging resulted in difficulties for sediment depth attribution during IODP Expedition 341. Jaeger et al., (2014) acknowledge that "In areas of lower core recovery, the exact lithostratigraphic unit boundaries may have an error range of a few meters due to recovered intervals being assumed to reside at the top of each cored interval [...]" [Jaeger et al., (2014); Core Log Seismic integration section].

This problem was also been observed, and accounted for, during ODP Leg 181 at Site 1123 (Shipboard Scientific Party, 2000).

15 In this instance, correlations were made between magnetic susceptibility measured in the recovered XCB cores and measured by the logging of the drilled hole. The results confirmed that the recovered "biscuits" were likely to have been distributed through each of the recovered core depths, rather than clustering in the upper few metres (Shipboard Scientific Party, 2000). However, Jaeger et al., (2014) had already considered this method during the development of the preliminary age model: "We combined sediment core observations and physical properties data with downhole logging data from Site

$20 \mathrm{U} 1417$ to (1) evaluate how representative the recovered cores are relative to the portion of the sedimentary section that was logged, (2) determine the nature and extent of sediment not recovered in the XCB/RCB drilling process, and (3) examine whether observed sedimentary units and features can be correlated to borehole data and ultimately be described at higher vertical resolution at Site U1417" [Jaeger et al., (2014); Core Log Seismic integration section; Lithostratigraphy-downhole logging data integration subsection]. Having compared magnetic susceptibility measurements from both recovered cores

25 and logging operations, correlation problems were noted, linked to the presence of diamicts and poor recoveries (as low as $21 \%)$ for some cores (Jaeger et al., 2014).

To test the impact of the assumption that sediment recovered belonged to the top core (the 'shipboard age model'), we propose a new CCSF-A depth model in response to evenly distributing sediment samples across each of the cores examined here, according to the methods outlined by Shipboard Scientific Party (2004) for ODP 1123. Our samples are linearly 30 distributed between fixed sample CCSF-A depths at the top and bottom of each core. We continue to apply the age-depth 
relationships generated by the shipboard age model respecting the magnetostratigraphic chronozones in Jaeger et al. (2014) to convert depth to age. The Gauss/Matuyama boundary at 2.581 Ma was clearly identified in Holes U1417B, U1417D and U1417E. Less confidence in identifying events below this reflect the impact of poor core recovery and the formation of the core biscuits (Jaeger et al., 2014).

\section{New age model:}

All samples presented in this study are from Hole U1417D with the exception of a single sample (U1417C 25H-3, shipboard average CCSF-A depth of $250.817 \mathrm{~m}$ ) (Fig. S1). The constrained magnetostratigraphic chronozone and sub-chronozone events found in Core U1417D are limited to C2r.1n (T) Reunion, C2An.1n (T) Gauss/Matuyama and the transition of C2An.3n (B) Gilbert/Gauss (Jaeger et al. 2014). Jaeger et al. (2014) propose a unified magnetostratigraphic ages and depths across U1417

10 cores using the composite depth scale "CCSF-A" (Fig. S1). Cores 26H-36X appear in continuous sedimentation in shipboard photographs and with no major core recovery losses. Therefore, the stretched model at these samples copies the shipboard age/depth model. Core 39X contains important gaps in sediment recovery, but the sediment recovered above our sample appears uninterrupted from the top core in the same "biscuit". This sample is kept on the shipboard age/depth. Our two samples at core 40X were also interpreted as being part of the same biscuit by revising the core photographs. The distance

15 between these samples were respected when applying the stretched age model. The ages/depths of samples contained in 41X-54X are stretched linearly downcore between top core and bottom core ages/depths. These top and bottom core ages and depths are fixed as tie points (Fig. S3B). The two last samples at core 54X keep the shipboard age/depth model for not having sampled sediment for biomarker analyses below U1417D 55X to follow our interpolation with the same criteria. The new stretched ages for the magnetic reversals at Site U1417 remain closest to the chronozone interpretations of Jaeger et 20 al., (2014) when comparing with the Geological Time Scale 2012 (Gradstein et al., 2012) magnetic reversals (Fig. S2 and S3a). The Olduvai and Reunion magnetic reversals are maintained as with the shipboard age model. The new Gauss/Matuyama magnetic reversal stretched age is similar than the shipboard age model, however, the Gilbert/Gauss transition moves from 3.75 Ma following shipboard age model to $3.88 \mathrm{Ma}$ in our new stretched age model (Fig. S2b and d and S3a). The Gilbert/Gauss transition was only found in Hole U1417D and due to its depth and poor core recovery it does not represent a

25 robust tie point to control our new age model. Our new age and depth models add detail in the sedimentation rates at Site U1417 (Fig. S3b). The comparison of our stretched age model with the LR04 benthic stack (Lisiecki and Raymo, 2005) suggests that the new age model preserves, or even enhances, the expression of glacial-interglacial climate variability which was not immediately visible from the original depth model (Fig. S2). 


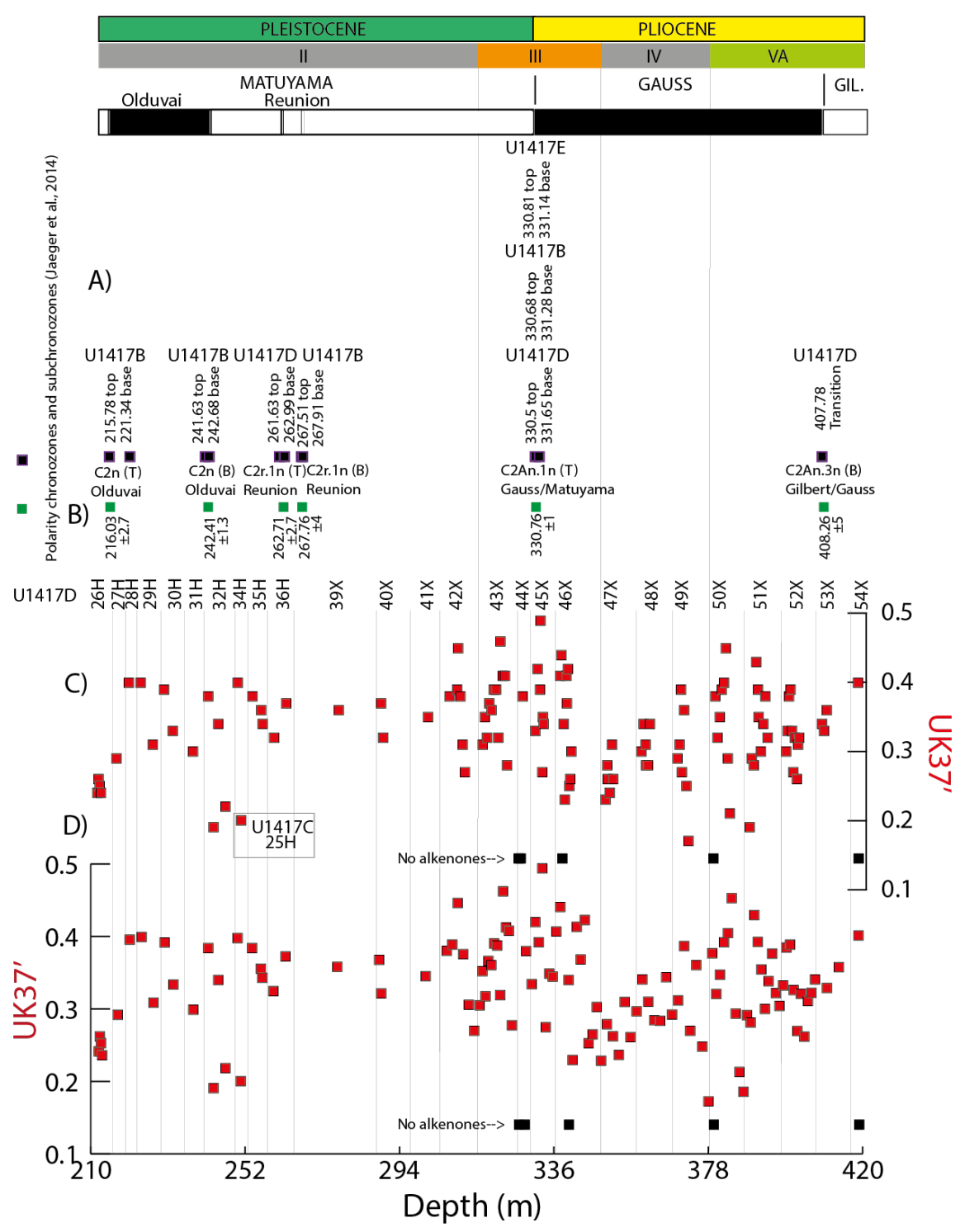

Figure S1: Comparison between shipboard depth model (Jaeger et al., 2014) and the depth model presented in this paper. On top, Pliocene and Pleistocene division by the Gauss/Matuyama magnetic reversal, lithostratigraphic units and colours as detailed in the main text and Site U1417 choronozone interpretations of (Jaeger et al., 2014), a) magnetostratigraphic chronozone and subchronozones depths

and interpretations present in different holes (Jaeger et al., 2014), b) Site U1417 unified magnetostratigraphic chronozone interpretations (Jaeger et al., 2014), d) Uk ${ }_{37}^{\prime}$ at Site U1417 plotted against the preliminary CCSF-A depths of (Jaeger et al., 2014) and e) UK ${ }_{37}^{\prime}$ at Site U1417 plotted against the new stretched depths. Black squares=samples with no alkenones. Shorter grey vertical lines indicate separation between U1417D cores and longer grey vertical lines indicate lithology unit boundaries. Grey square delimits the only sample belonging to Hole U1417C. 


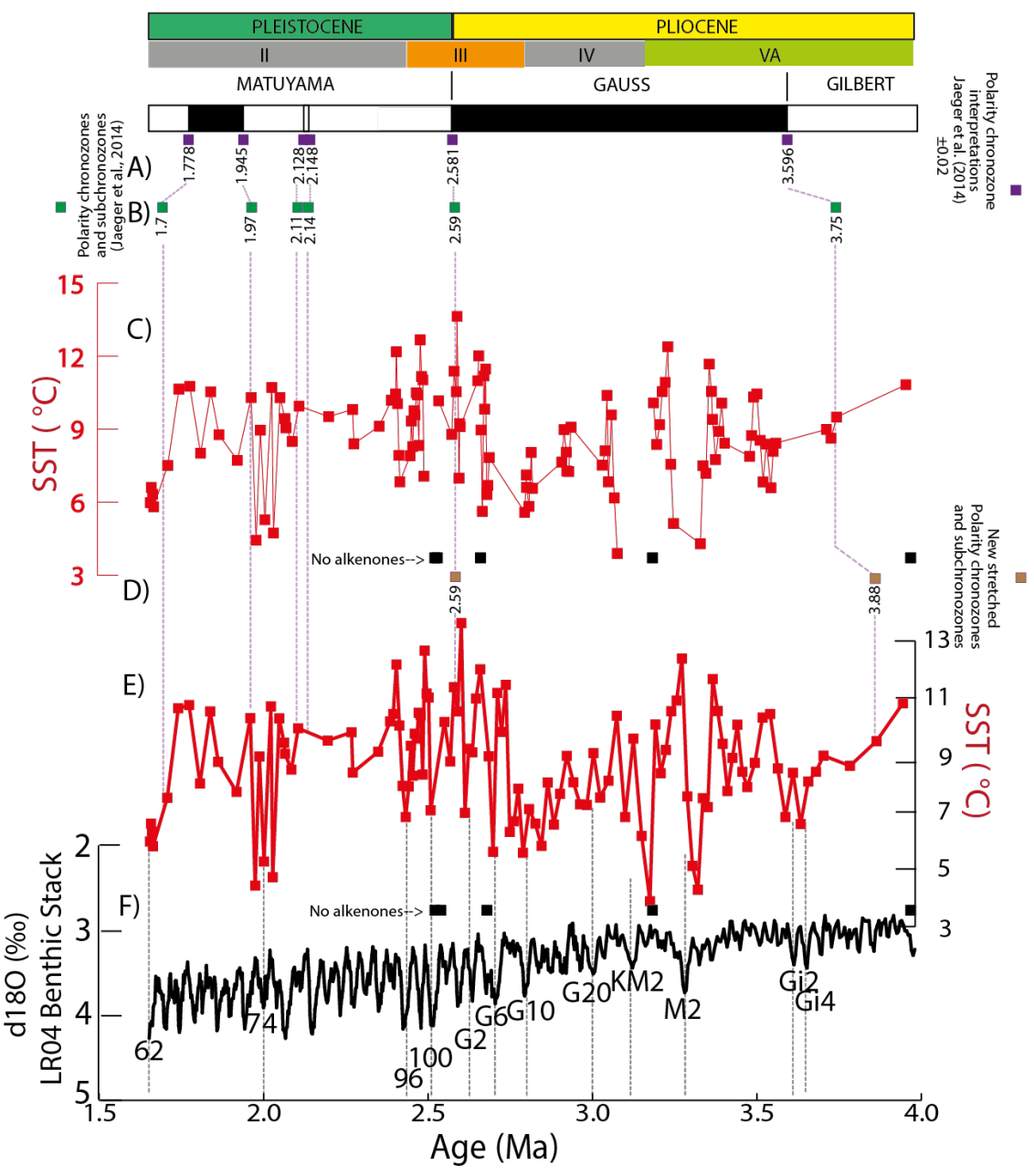

Figure S2: Sea surface temperatures of U1417 plotted with the new age model proposed here and compared to the LR04 (Lisiecki and Raymo, 2005). On top, Pliocene and Pleistocene division, lithostratigraphic units and colours as detailed in the main text and the magnetostratigraphic chronozone interpretation (Jaeger et al., 2014) a) polarity chronozone interpretation ages (Jaeger et al., 2014), b) 5 polarity chronozone interpretation ages calculated from the CCSF-A of Figure S1, c) SST (calculated from Müller et al., 1998 calibration) at Site U1417 plotted against the shipboard age model of (Jaeger et al., 2014), d) polarity chronozone interpretation ages according to our new stretched model, e) SST (calculated from Müller et al., 1998 calibration) at Site U1417 plotted against the new stretched age model and f) LR04 benthic stack (Lisiecki and Raymo, 2005) and distinctive marine isotope stadials. Black squares represent samples with no alkenones and purple vertical lines represent the correlation of magnetostratigraphic chronozone ages across panels. 


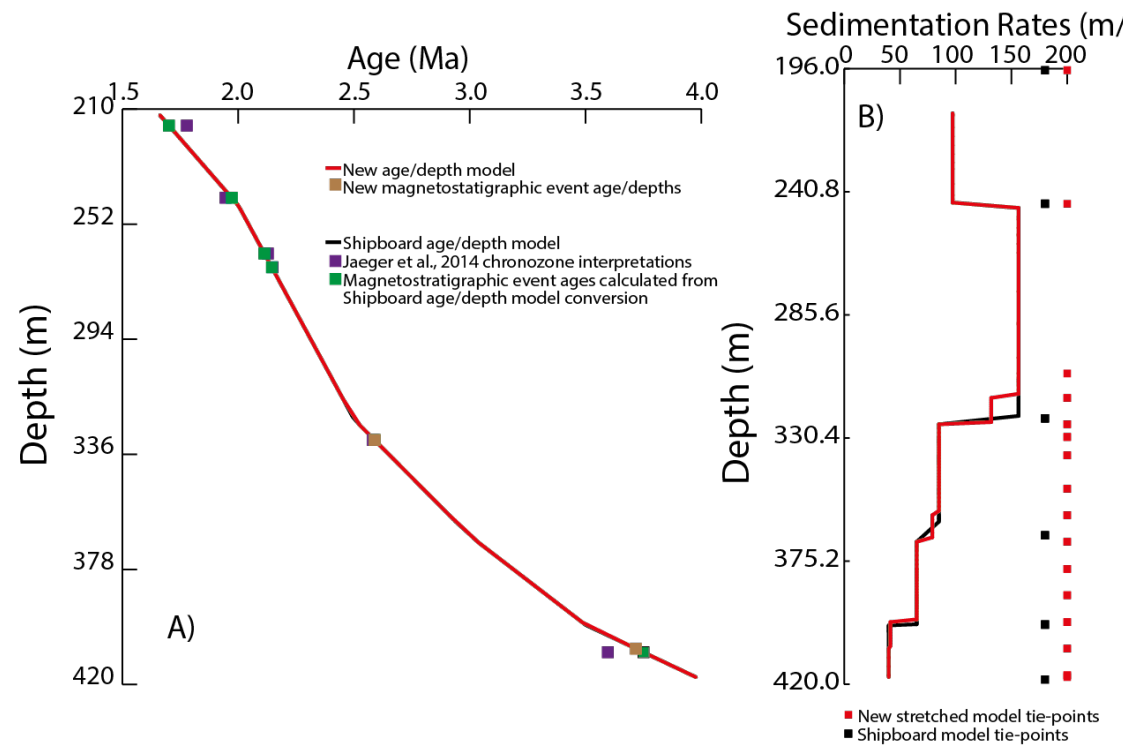

Figure S3: Shipboard and new age/depth model comparisons. a) shipboard (black line, Jaeger et al., 2014) and new stretched (red line) age/depth models. Magnetostratigraphy chronozone interpretations depth and ages as assigned in Jaeger et al., 2014 (purple squares), Magnetostratigraphy chronozone calculated ages from the shipboard CCSF-A depth/age model of Jaeger et al., 2014 and ages calculated

5 according to the new stretched age model (brown squares); b) average sedimentation rates ( $\mathrm{m}$ Myr ${ }^{-1}$ ) with the detailed tie points considered following the shipboard (in black) and new stretched (in red) age/depth models.

\section{References}

Gradstein, F.M., Ogg, J.G., Schmitz, M., Ogg, G., The geologic time scale 2012, Elsevier, 2012.

Jaeger, J.M., Gulick, S.P.S., LeVay, L.J., Asahi, H., Bahlburg, H., Belanger, C.L., Berbel, G.B.B., Childress, L.B., Cowan, E.A., Drab,

10 L., Forwick, M., Fukumura, A., Ge, S., Gupta, S.M., Kioka, A., Konno, S., Marz, C.E., Matsuzaki, K.M., McClymont, E.L., Mix, A.C., Moy, C.M., Müller, J., Nakamura, A., Ojima, T., Ridgway, K.D., Rodrigues Ribeiro, F., Romero, O.E., Slagle, A.L., Stoner, J.S., St-Onge, G., Suto, I., Walczak, M.H., and Worthington, L.L., Site U1417, 2014. In Jaeger, J.M., Gulick, S.P.S., LeVay, L.J., and the Expedition 341 Scientists, Proc. IODP, 341: College Station, TX (Integrated Ocean Drilling Program). doi:10.2204/iodp.proc.341.103, 2014.

15 Lisiecki, Lorraine E; Raymo, Maureen E, Pliocene-Pleistocene stack of globally distributed benthic stable oxygen isotope records. PANGAEA, https://doi.org/10.1594/PANGAEA.704257,2005. Supplement to: Lisiecki, LE; Raymo, ME, A PliocenePleistocene stack of 57 globally distributed benthic d180 records. Paleoceanography, 20, PA1003, https://doi.org/10.1029/2004PA001071, 2005.

Müller P. J., Kirst G., Ruhland G., von Storch I., and Rosell-Melé A., Calibration of the alkenone paleotemperature index $U^{K}{ }_{37}^{\prime}$

20 based on core-tops from the eastern South Atlantic and the global ocean (608 N-608 S), Geochim. Cosmochim. Acta 62, 1757-1772, doi:10.1016/S0016-7037(98)00097-0, 1998. 
Shipboard Scientific Party, Site 1123: North Chatham Drift - a 20 Ma Record of the Pacific Deep Western Boundary Current, 2000. In Carter, R.M., McCave, I.N., Richter, C., Carter, L., et al., Proc. ODP, Init. Repts., 181, 1-184. 